\title{
Variations in morphological traits, agronomic traits and traits related to drought tolerance in indigenous Thai rice varieties
}

\author{
Sumran Pimratch ${ }^{\mathrm{a}}$, Tantika Mungkunkamchao ${ }^{\mathrm{b}}$, Thawan Kesmala ${ }^{\mathrm{c}, *}$ \\ a Programme in Agriculture, Faculty of Agricultural Technology, Rajabhat Maha Sarakham University, \\ Maha Sarakham 44000 Thailand \\ b Udon Thani Land and Development Station, Udon Thani 41130 Thailand \\ c Department of Plant Science and Agricultural Resources, Faculty of Agriculture, Khon Kaen University, \\ Khon Kaen 40002 Thailand
}

*Corresponding author, e-mail: thkesmala@gmail.com

Received 31 Aug 2018

Accepted 29 Apr 2019

\begin{abstract}
Indigenous rice is worth conserving as it possesses many important traits such as good table quality for consumers, resistance to biotic and abiotic stresses and, especially, quality of starch. The objectives of this study were to evaluate indigenous rice accessions collected in Northeast Thailand and select the superior accessions for further improvement of indigenous rice. Forty indigenous rice accessions were evaluated in a pot experiment in a split-plot design with completely randomized arrangement of the treatments and four replications for two years in 2014 and 2015. Main plots were two water regimes, including well-irrigated treatment and early season drought treatment; the subplots included 40 indigenous rice accessions. Well-irrigated treatment was higher than early season drought condition in terms of plant height, number of tiller per plants, number of ears per plant, number of unfilled grains per ear, grain weight per plant, straw weight per plant and shoot dry weight per plant; drought treatment was higher than irrigated treatment in terms of the number of filled grains per plant, 1000-grain weight and root dry weight; whereas these two types of treatment showed no differences in terms of the number of tillers/plant at 30 days after emergence and harvest index. The superior genotypes for each trait and the genotypes with better drought tolerance index were identified.
\end{abstract}

KEYWORDS: drought tolerance index, early season drought, water regimes, well-irrigated treatment

\section{INTRODUCTION}

Rice is a staple food crop in Asia. In Thailand, the land area used for planting rice has been estimated at 10397920 ha with the country producing 21424000 t of rice in $2018^{1}$. However, the country's productivity has been recorded as being rather low, accounting for only $2.7 \mathrm{t} \mathrm{ha}^{-1}$. The low productivity of rain-fed rice is mainly due to droughts occurring each stage of rice growth, especially in the growing areas in Northeast Thailand which was estimated to comprise $60 \%$ of the country's overall rice growing area.

Drought at seedling stage could cause a yield loss of $25 \%{ }^{2}$, while drought at flowering and grain filling stages could cause severe yield losses (29$40 \%)^{3}$. It is very difficult to irrigate the crop in the rain-fed areas, thus the use of drought-resistant varieties is a promising option to improve the sustainability of crop productivity under drought con- ditions.

Screening of germplasm sources for drought resistance is used as an initial step to develop droughtresistant varieties. Indigenous rice is interesting for use as a germplasm source for drought resistance as this type of rice has long been cultivated in harsh environments and has good adaptation to environments. In China, traditional upland rice is used to transfer drought resistance to commercial lowland rice $^{4}$. In a study in Thailand, 60 accessions of rice landraces were classified into three groups, including tolerant genotypes, intermediate genotypes and susceptible genotypes based on the drought resistance index ${ }^{5}$. In a study for salt tolerance of rice landraces in Northeast Thailand, nine out of a total of 30 landraces were found to be salt-tolerant at seedling stage ${ }^{6}$.

Some traits of indigenous rice varieties are unique, such as aromatic trait, salt tolerance, 
drought tolerance, disease and pest-resistance, high nutrition, antioxidant and stickiness ${ }^{7}$. In India, the majority of indigenous rice varieties are disease and pest-resistant varieties suitable for lowland cultivation and some varieties are also resistant to waterlogging and flooding ${ }^{8}$.

Although most indigenous rice varieties have good agronomic traits and are unique for growing areas, these varieties are gradually disappearing from cultivation, especially in irrigated areas. It is important to collect, conserve and evaluate indigenous rice varieties for further use as germplasm sources for rice breeding. The assumption underlying this study project is that indigenous rice should possess some extent of variations in grain yield, agronomic traits and traits related to drought resistance. The objectives of this study were to evaluate indigenous rice accessions collected in Northeast Thailand and select the superior accessions for the further improvement of indigenous rice. The information obtained in this study is useful for the advanced evaluation of these indigenous accessions for possible release and selection of superior genotypes for use as parents in indigenous rice breeding.

\section{MATERIALS AND METHODS}

\section{Plant materials and experiment design}

Forty indigenous rice accessions were collected in Northeastern Thai provinces, including Mahasarakham, Roi Et, Kalasin, Khon Kaen, Sakon Nakhon, Nakhon Phanom, Nong Khai, Yasothon, Ubon Ratchathani and other nearby provinces from November 2014 to April 2015. The details of the collection sites are given in Table 1 . These accessions were evaluated in terms of drought resistance in a split-plot design with treatment arrangement in a completely randomized design with four replications for two years in 2014 and 2015. Water regimes with well-irrigated treatment and early season drought treatment were assigned in the main plots, and 40 indigenous rice accessions were assigned in subplots.

\section{Crop management}

The soil in the experiment was first collected from the rice field, then air-dried and sieved through 80mesh screen. The soil samples were also taken from the bulk of soil for soil analysis according to standard laboratory protocols for soil's physical and chemical properties including sand, silt, clay, total nitrogen, available phosphorus, extractable potassium, extractable calcium, $\mathrm{pH}$, cation exchange
Table 1 The indigenous rice accessions kindly donated from six organizations, including Khon Kaen Rice Research Center (KKRRC), Surin Rice Research Center (SRRC), the groups of farmers for conservation of indigenous rice in Yasothon province (YP), Kalasin Province (KP), Maha Sarakham province (MSP), and Sakon Nakhon province (SNP).

\begin{tabular}{lclc}
\hline Accession & Location & Accession & Location \\
\hline Som Ma Lee & KP & Hom Dong & SRRC \\
Mali Dung Derm & YP & Sumpun Deang & MSP \\
Khao Yai & SRRC & Kaw Dor & MSP \\
Laum Phou & SNP & Kaen Doo & KP \\
Ku Larb Dum & KKRRC & Nang Mon & KKRRC \\
Wid Nee & KP & Hin Kong & KP \\
Pa Ka Amphuen & SRRC & San Pla Lard & YP \\
E-Noi & KP & Lueng Kaew & YP \\
Kum Ka Dum & KP & Lueng Yai & YP \\
Khao Park Mor & KP & Nang Hok & KP \\
Chao Deang & MSP & Kum Pay & MSP \\
Rark Phai & KP & Kore Deaw & KP \\
Hom Klong Luang & KKRRC & Kaw Muang & KKRRC \\
Leaung Kum Mad & YP & Hom Nang Nuan & KKRRC \\
Dore Khoa & MSP & Naew Deang & KP \\
Pa Ma & MSP & Lueng Boon Ma & YP \\
Num Sa Kouy 19 & KP & Hom Sakon & KKRRC \\
Kun Dun Tia & KKRRC & Ku Muang Luang & KP \\
San Pa Thong & SRRC & KDML 105 & KKRRC \\
Pha Daeng & SRRC & RD 6 & KKRRC \\
\hline
\end{tabular}

(CEC) and organic matter. The data of soil properties were used for calculating the soil's waterholding capacity, water to be applied to the crop and fertilizer rates.

The forty accessions of indigenous rice were evaluated for yield, yield components, agronomic traits and the traits related to drought resistance in a pot experiment under well-irrigated and drought conditions in the field at the Faculty of Agricultural Technology, Mahasarakham Rajabhat University for two years from May to November in both 2014 and 2015. The crop was planted in plastic containers $30 \mathrm{~cm}$ in diameter and $30 \mathrm{~cm}$ in height and each container accommodated one plant. Two containers were considered to be one plot in a replication and there were eight containers for each accession in four replications. Hence the experiment in each year had 640 containers in total, which were divided into two groups consisting of 320 containers for wellirrigated treatment and 320 containers for early season drought treatment.

Three to five seeds were planted in each container. After planting, water was applied to the crop 
at field capacity for good seed germination and good crop establishment. The seedlings were thinned to obtain one plant per container at seven days after emergence (DAE). Chemical fertilizer formula 1616-8 of N-P-K was applied to the crop at the rate of $187.5 \mathrm{~kg} \mathrm{ha}^{-1}$ at $15 \mathrm{DAE}$, and nitrogen fertilizer in the form of urea (46-0-0) was applied to the crop at the rate of $62.5 \mathrm{~kg} \mathrm{ha}^{-1}$ at 60 DAE. Manual weeding was carried out regularly to control weeds. For wellirrigated treatment, flood water was applied to the crop at $10-15 \mathrm{~cm}$ above the soil surface at tillering stage until physiological maturity.

For drought treatment, water at field capacity level was stopped at $30 \mathrm{DAE}$ in order to commence the drought for a period of 28 days. The soil was gradually dried until it reached the driest level at 28 days after water withholding. This practice was done to mimic drought conditions at the early growth stage. After a drought period of 28 days, water was applied to the crop at field capacity until physiological maturity. Amounts of water that were applied to the crop for both well-irrigated and drought treatments were calculated according to Doorenbos et $\mathrm{al}^{9}$.

\section{Data collection}

The data were recorded for number of tillers, plant height days to flowering, grain yield and yield components. Number of tillers was recorded at flowering and harvest stages. Plant height was measured at 30,60, and 90 days after emergence and at harvest. Before flowering, plant height was measured from the soil surface to the highest point of the leaves, and, after flowering, plant height was measured from the soil surface to the highest point of the ear. Plant height was averaged from all plants in the plot. The number of days to flowering was recorded from the first day of blooming to the day when $50 \%$ of the plants in the plot had shed pollen.

At harvest, the data were recorded for grain weight per plant, 1000-grain weight, number of ears per plant, number of grains per ear, number of filled grains, number of unfilled grains, total dry weight and harvest index, which was calculated as grain weight/total dry weight.

\section{Traits related to drought resistance}

Traits related to drought resistance, including leaf rolling score, drought scoring and drought recovery were recorded at appropriate times and these traits were evaluated under drought treatment only. Leaf rolling score indicates the response of plants to drought by rolling the leaves for five levels, and this trait was evaluated according to the method suggested by De Datta et $\mathrm{al}^{10}$ as follows: (1) normal leaf without rolling, (2) leaf margins bend inward slightly, (3) leaf margins bend inward greatly, (4) leaf margins bend and are close to each other, and (5) leaf margins bend and make contact with each other.

Drought scoring is a symptom of leaves in response to drought occurring after leaf rolling. Ten levels of drought scoring rating were recorded, and the traits were evaluated according to the method described by De Datta et $\mathrm{al}^{10}$ as follows: (0) normal leaf, (1) slightly dry at the end of leaf, (2) dry at the end of leaf for $25 \%$, (3) dry at the end of leaf for $50 \%$, (4) dry at the end of leaf for more than $50 \%$ and leaf necrosis for $25 \%$, (5) whole leaf dry $50 \%$, (6) whole leaf dry more than $50 \%$ but less than $70 \%$, (7) whole leaf dry $70 \%$, (8) whole leaf dry more than $70 \%$, and (9) whole leaf dry $100 \%$.

Drought recovery is the ability of plant to recover from drought after the end of a drought period. The traits were evaluated at 10 days after rewatering by using a scoring system with five levels of drought recovering scores according to the method described by IRRI ${ }^{11}$ as follows: (1) recover 90 $100 \%$, (3) recover $70-89 \%$, (5) recover $40-69 \%$, (7) recover $20-39 \%$, and (9) recover 0-19\%.

Drought tolerance index (DTI) was also calculated for all traits. The indexes indicated the degree of drought tolerance for these traits as suggested by Nautiyal et $\mathrm{al}^{12}$. The genotypes with higher drought tolerance index had better adaptation to drought than the genotypes with lower drought tolerance index. The calculation for DTI is stress treatment/non-stress treatment.

\section{Data analysis}

Data were analysed according to a split-plot design with treatment arrangement in a completely randomized design and four replications. At the first step of data analysis, the data for each year were analysed individually, and the error variances for each trait were compared for variance homogeneity according to Gomez ${ }^{13}$, and the difference of error variances lower than three folds was considered homogeneous. At the second step, the data with variance homogeneity were combined with an ANOVA of the data for two years. The data for traits that related to drought resistance were analysed separately according to a completely randomized design because these traits could not be evaluated under well-watered condition. Mean differences were separated by Duncan's multiple range test 
(DMRT) at a probability level of 0.05. All calculations as part of the ANOVA were performed by using MSTAT-C soltware ${ }^{14}$. Cluster analysis based on all characters under the study was performed using Ward's method and squared Euclidean distance method. All calculations were performed using JMP Pro software (version 10.0, SAS institute Inc., Chicago, USA).

\section{RESULTS}

Year

Years were significantly different $(p \leqslant 0.05)$ for plant height, number of tillers per plant and number of ears per plant (Table 2). Years were also significantly different $(p \leqslant 0.05)$ for the number of filled grains/ear, number of unfilled grains/ear, 1000grain weight, grain weight/plant, straw weight/ plant, root dry weight/plant, shoot dry weight/ plant and harvest index (Table 3).

The crop planted in 2014 was significantly higher $(p \leqslant 0.05)$ than the crop planted in 2015 for plant height at 30,60,90, and 120 days after emergence (DAE) (data not shown), and it was also significantly higher than the crop planted in 2015 for the number of tillers per plant at 30 DAE. However, the crop planted in 2014 was significantly lower $(p \leqslant 0.05)$ than the crop planted in 2015 in terms of the number of tillers per plant at 60 and $90 \mathrm{DAE}$ and number of ears per plant. The crop planted in 2015 was significantly higher $(p \leqslant$ 0.05) than the crop planted in 2014 in terms of the number of filled grains/ear, number of unfilled grains/ear, 1000-grain weight, grain weight/plant, straw weight/plant, root dry weight/plant, shoot dry weight/plant, but it was significantly lower $(p \leqslant$ 0.05 ) than the crop planted in 2014 for the harvest index (data not shown).

\section{Water regime}

Water regimes were significantly different $(p \leqslant$ 0.05 ) for most traits except for the number of tillers/plant at 30 DAE and harvest index (Tables 2 and 3). Numbers of tillers/plant at 30 DAE and the harvest index were not significantly different by water level. Well-irrigated crop was significantly higher $(p \leqslant 0.05)$ than the crop subjected to early season drought for plant height at 90 and 120 DAE, number of tillers per plant at 60 and 90 DAE, number of ears/plant, number of unfilled grains/ear, grain weight/plant, straw weight/plant and shoot dry weight/plant, but it was significantly lower $(p \leqslant 0.05)$ than the crop subjected to early season drought for plant height at 30 and $60 \mathrm{DAE}$, number of filled grains/ear, 1000-grain weight and root dry weight (data not shown).

\section{Rice accession}

As the error variances for all characters were homogeneous, the data of two years were combined and ANOVA and mean values of the two years of data were reported. Indigenous rice accessions were significantly different $(p \leqslant 0.05)$ for plant height at $30,60,90$, and $120 \mathrm{DAE}$, number of tillers per plant at 30,60, and $90 \mathrm{DAE}$ and number of ears at harvest (Table 2). For all accessions, plant height increased with time from 30 DAE to 120 DAE. At 120 DAE, the lowest plant heights of $95.4 \mathrm{~cm}$ were recorded in Ku Larb Dum and Hom Klong Luang, whereas the highest plant height of $155 \mathrm{~cm}$ was recorded in Kum Ka Dum (data not shown). The other accessions were in the range of these accessions, and, therefore, the groups of accessions with tall plants or short plants could be clearly identified.

As with plant height, the number of tillers per plant also increased with time from 30 DAE to 90 DAE. The lowest tiller number of 14.03 tillers was recorded in Laum Phou, whereas the highest tiller number of 32.50 tillers was recorded in Chao Deang. Other indigenous rice accessions were within this range for the number of tillers per plant. The high group and the low group were identified for further use in breeding programs. In general, plant height was negatively correlated with the number of tillers per plant $(r=0.05,-0.43$, and -0.62 for 30,60 , and $90 \mathrm{DAE}$, respectively). The number of panicles per plant at harvest (120 DAE) was also negatively correlated with plant height $(r=-0.62)$. (Data for correlations are available upon request).

The lowest ear number per plant of 10.6 ears was recorded in Kum Ka Dum, and this accession also had the shortest plant and lowest tiller number. The highest ear number per plant of 27.8 ears was recorded in Kun Dun Tia. The other accessions were intermediate between these extremes, and the accessions with low or high ear number per plant were identified.

The indigenous rice accessions were also significantly different $(p \leqslant 0.05)$ in terms of the number of filled grains/ear, number of unfilled grains/ear, 1000-grain weight, grain weight/plant, straw weight/plant, root dry weight/plant, shoot dry weight/plant and harvest index (Table 3 ). The numbers of filled grains ranging from 43.6 grains in Laum Phou to 123.1 grains in Kaw Muang were recorded among indigenous rice accessions, 
Table 2 Mean square values for plant height at 30,60, 90, and 120 DAE, number of tillers per plant at 30, 60, and 90 DAE and number of ears/plant of 40 indigenous rice accessions planted under 2 water regimes of well-irrigated and early season drought conditions for two years in 2014 and 2015.

\begin{tabular}{|c|c|c|c|c|c|c|c|c|c|}
\hline \multirow{2}{*}{$\begin{array}{l}\text { Source of } \\
\text { variation }\end{array}$} & \multirow[t]{2}{*}{$\mathrm{df}$} & \multicolumn{4}{|c|}{ Plant height } & \multicolumn{3}{|c|}{ Number of tillers/plant } & \multirow{2}{*}{$\begin{array}{l}\text { Number of } \\
\text { ears/plant }\end{array}$} \\
\hline & & 30 DAE & $60 \mathrm{DAE}$ & 90 DAE & 120 DAE & $30 \mathrm{DAE}$ & $60 \mathrm{DAE}$ & $90 \mathrm{DAE}$ & \\
\hline Season (S) & 1 & $640.0 * *$ & $160.0 * *$ & $640.0 * *$ & $111.4 * *$ & $79.4 * *$ & $12509.5 * *$ & $97787.4 * *$ & $20748.0 * *$ \\
\hline Within season & 6 & $100.8 * *$ & $370.0 * *$ & $318.9 * *$ & $1284.7 * *$ & $87.2^{* *}$ & $364.2^{* *}$ & $221.6 * *$ & $126.3 * *$ \\
\hline Water level (W) & 1 & $514.8 * *$ & $748.2 * *$ & $8806.1^{* *}$ & $6033.2 * *$ & 0.9 & $9139.3 * *$ & $2636.6 * *$ & $448.9 * *$ \\
\hline SW & 1 & 0.0 & 0.0 & 0.0 & 4.4 & $148.7 * *$ & $5161.4 * *$ & $909.6 * *$ & 0.0 \\
\hline Variety (V) & 39 & $532.8 * *$ & $1764.1^{* *}$ & $2435.0 * *$ & $2960.6 * *$ & $51.1^{* *}$ & $94.9 * *$ & $384.9 * *$ & $290.4 * *$ \\
\hline SV & 39 & 0.0 & 0.0 & 0.0 & 2.2 & $17.6^{* *}$ & $42.5 * *$ & $223.3 * *$ & $124.0 * *$ \\
\hline WV & 39 & $89.6 * *$ & $389.8 * *$ & $486.9 * *$ & $151.1 * *$ & 6.2 & $39.0 * *$ & $85.6 * *$ & $63.2^{* *}$ \\
\hline SWV & 39 & 0.0 & 0.0 & 0.0 & 2.2 & $6.7^{*}$ & $38.8 * *$ & $89.8 * *$ & $56.6 * *$ \\
\hline Error & 474 & 21.25 & 48.96 & 65.36 & 68.17 & 4.65 & 17.80 & 23.97 & 18.45 \\
\hline C.V. (\%) & - & 8.42 & 8.44 & 8.07 & 6.27 & 28.88 & 29.37 & 19.92 & 21.84 \\
\hline
\end{tabular}

*,** Significant at $p \leqslant 0.05$ and $p \leqslant 0.01$, respectively.

Table 3 Mean square values for number of filled grains/ear, number of unfilled grains/ear, 1000-grain weight, grain weight/plant, straw weight/plant, root dry weight/plant, shoot dry weight/plant, and harvest index of 40 indigenous rice accessions planted under 2 water regimes of well-irrigated and early season drought conditions for two years in 2014 and 2015.

\begin{tabular}{|c|c|c|c|c|c|c|c|c|c|}
\hline $\begin{array}{l}\text { Source of } \\
\text { variation }\end{array}$ & df & $\begin{array}{r}\text { Filled grains } \\
\text { (no./ear) }\end{array}$ & $\begin{array}{r}\text { Unfilled grains } \\
\text { (no./ear) }\end{array}$ & $\begin{array}{r}\text { 1000-grain } \\
(\mathrm{g})\end{array}$ & $\begin{array}{r}\text { Grain } \\
\text { (g/plant) }\end{array}$ & $\begin{array}{r}\text { Straw } \\
\text { (g/plant) }\end{array}$ & $\begin{array}{r}\text { Root dry } \\
\text { (g/plant) }\end{array}$ & $\begin{array}{l}\text { Shoot dry } \\
\text { (g/plant) }\end{array}$ & $\begin{array}{l}\text { Harvest } \\
\text { index }\end{array}$ \\
\hline Season (S) & 1 & $39085.8 * *$ & $6539.5 * *$ & $8022.7 * *$ & $19430.2 * *$ & $1302835.5^{* *}$ & $191081.5 * *$ & $1640498.1 * *$ & $0.771^{* *}$ \\
\hline Within season & 6 & $4407.4^{* *}$ & $448.5^{* *}$ & $150.8 * *$ & $1347.0 * *$ & $12541.2^{* * *}$ & $2977.9^{* *}$ & $19730.1 * *$ & 0.016 * \\
\hline Water level (W) & 1 & $11077.2^{* *}$ & $15826.2 * *$ & $66.8 * *$ & $4238.3 * *$ & $38747.7^{* *}$ & $597.0 *$ & $68619.5 * *$ & 0.000 \\
\hline SW & 1 & $14816.8 * *$ & $4189.3^{* *}$ & 14.7 & 0.0 & 34.1 & $1029.7 * *$ & 36.4 & 0.002 \\
\hline Variety (V) & 39 & $5187.0 * *$ & $2427.2^{* *}$ & $331.2 * *$ & $1072.1 * *$ & $7838.2 * *$ & $1171.0 * *$ & $9409.3^{* *}$ & $0.032 * *$ \\
\hline SV & 39 & $2569.3 * *$ & $2314.6^{* *}$ & $84.8 * *$ & $845.9 * *$ & $3706.2^{* *}$ & $1129.7^{* *}$ & $5889.0 * *$ & $0.016 *$ \\
\hline WV & 39 & $2176.7 * *$ & $1413.2 * *$ & 12.3 & $325.5 * *$ & $1244.7 * *$ & 129.6 & $1608.0 * *$ & $0.007^{*}$ \\
\hline SWV & 39 & $2333.1 * *$ & $695.8 * *$ & $24.0 * *$ & $234.7 * *$ & $1345.5 * *$ & 103.9 & $1462.5 * *$ & $0.007^{*}$ \\
\hline Error & 474 & 1320.54 & 343.69 & 9.85 & 19.75 & 378.63 & 109.76 & 410.86 & 0.002 \\
\hline C.V. $(\%)$ & - & 43.68 & 56.99 & 10.47 & 13.87 & 15.69 & 33.05 & 12.99 & 20.01 \\
\hline
\end{tabular}

**** Significant at $p \leqslant 0.05$ and $p \leqslant 0.01$, respectively.

whereas the numbers of unfilled grains ranging from 14.4 grains in Hom Nang Nuan to 63.9 grains were observed in Pa Ka Amphuen (data not shown). The number of filled grains and number of unfilled grains were somewhat negatively correlated $(r=$ -0.39 ).

The highest 1000 -grain weight $(42.7 \mathrm{~g})$ was observed in Nang Hok and the lowest 1000-grain weight (20.7 g) was observed in Sumpun Deang. San Pa Thong had the highest grain weight per plant (53.4 g), whereas Leaung Kum Mad had the poorest performance for this trait $(18.0 \mathrm{~g})$. Straw weights ranging from $73.5 \mathrm{~g} /$ plant in Laum Phou to $169.4 \mathrm{~g} /$ plant in Leaung Kum Mad were observed among indigenous rice accessions. Other accessions were intermediate between these extreme accessions.

Root dry weights among indigenous rice ac- cessions ranged from $17.4 \mathrm{~g} / \mathrm{plant}$ in KDML 105 to $48.3 \mathrm{~g} /$ plant in Mali Dung Derm, which was similar to $47.7 \mathrm{~g} /$ plant of Khao Park Mor. Shoot dry weights among indigenous rice accessions ranged from $92.4 \mathrm{~g} /$ plant in Laum Phou to $193.6 \mathrm{~g} /$ plant in Pha Daeng. The accessions with a high shoot dry weight included those in Khao Yai (192.5 g/plant) and Ku Muang Luang (192.8 g/plant). The variation in the harvest index among indigenous rice accessions was rather high, ranging from 0.10 in Leaung Kum Mad to 0.30 in Kaw Dor.

\section{Interaction effects}

The interaction effects for plant height at 30,60, 90 , and 120 DAE were significant $(p \leqslant 0.01)$ between water regime and rice variety but the effects were not significant between season and water regime; season and variety; and among season, wa- 
ter regime and variety (Table 2). Most interaction effects for the number of tillers/plant at 30,60, and 90 DAE were significant $((p \leqslant 0.05)$ or 0.01$)$ except for the interaction effect between water regime and variety at $30 \mathrm{DAE}$. Most interaction effects for number of ears/plant were significant $(p \leqslant 0.01)$ except between season and water regime.

All interaction effects were significant $(p \leqslant$ 0.01 ) for number of filled grains/ear and number of unfilled grains/ear (Table 3). The interaction effects for 1000-grain weight were significant ( $p \leqslant$ 0.01 ) between season and variety; and among season, water regime and variety; whereas other effects were not significant. Most interaction effects for grain weight/plant, straw weight/plant, shoot dry weight and harvest index were significant $(p \leqslant$ 0.01 ) except the interaction effects between season and water regime, whereas the interaction effects for root dry weight were significant $(p \leqslant 0.01)$ between season and water regime and between season and variety only.

\section{Traits related to drought tolerance}

Leaf rolling score and drought scoring were evaluated twice. Both evaluations found the leaf rolling score not to be significant, whereas drought scoring was significant $(p \leqslant 0.05)$ at the second time of evaluation only (Table 4). There was low variation for drought scoring in the evaluation at the second time, ranging from 4.75 in Wid Nee to 7.12 in Mali Dung Derm. Mali Dung Derm, Khao Yai, Leaung Kum Mad and Kaen Doo had high drought scoring, ranging from 6.87-7.12, which were significantly higher than 4.75 of Wid Nee. Other accessions were intermediate between these groups.

The rice accessions were significantly different ( $p \leqslant 0.05$ ) for drought recovery, ranging from 2.50 in Kum Ka Dum, Kun Dun Tia, Kum Pay and Lueng Boon Ma to 4.75 in Khao Yai, and these groups were significantly different $(p \leqslant 0.05)$, whereas other accessions were intermediate between these groups. When all drought-related traits are considered, Khao Yai might be a promising accession for drought resistance.

\section{Drought tolerance index}

Drought tolerance index (DTI) is the ratio of performance of any trait under drought and wellirrigated conditions. A high index score indicates good performance under drought and vice versa. The indigenous rice accessions were significantly different for drought tolerance index $(p \leqslant 0.05)$ for
Table 4 Leaf rolling score (evaluated 2 times), drought scoring (evaluated 2 times) and drought recovery of 40 indigenous rice accessions grown under early season drought from June to December in 2014 and 2015.

\begin{tabular}{|c|c|c|c|c|c|}
\hline \multirow[t]{2}{*}{ Accession } & \multicolumn{2}{|c|}{ Leaf rolling score } & \multicolumn{2}{|c|}{ Drought scoring } & \multirow{2}{*}{$\begin{array}{l}\text { Drought } \\
\text { recovery }\end{array}$} \\
\hline & 1 & 2 & 1 & 2 & \\
\hline Som Ma Lee & 3.37 & 4.87 & 2.12 & $5.37^{\mathrm{ab}}$ & $2.75^{\mathrm{ab}}$ \\
\hline Mali Dung Derm & 3.87 & 4.75 & 4.12 & $7.12^{\mathrm{a}}$ & $3.75^{\mathrm{ab}}$ \\
\hline Khao Yai & 3.50 & 4.50 & 4.50 & $7.00^{\mathrm{a}}$ & $4.75^{\mathrm{a}}$ \\
\hline Laum Phou & 3.50 & 4.87 & 2.87 & $6.62^{\mathrm{ab}}$ & $3.00^{\mathrm{ab}}$ \\
\hline Ku Larb Dum & 3.37 & 4.37 & 2.75 & $5.50^{\mathrm{ab}}$ & $3.00^{\mathrm{ab}}$ \\
\hline Wid Nee & 3.12 & 4.12 & 2.50 & $4.75^{\mathrm{b}}$ & $3.00^{\mathrm{ab}}$ \\
\hline Pa Ka Amphuen & 3.75 & 5.00 & 3.37 & $6.12^{\mathrm{ab}}$ & $3.50^{\mathrm{ab}}$ \\
\hline E-Noi & 3.75 & 4.62 & 3.75 & $5.75^{\mathrm{ab}}$ & $3.00^{\mathrm{ab}}$ \\
\hline Kum Ka Dum & 3.12 & 4.37 & 2.62 & $5.62^{\mathrm{ab}}$ & $2.50^{\mathrm{b}}$ \\
\hline Khao Park Mor & 4.00 & 4.87 & 4.25 & $6.25^{\mathrm{ab}}$ & $4.00^{\mathrm{ab}}$ \\
\hline Chao Deang & 3.37 & 4.37 & 3.25 & $5.25^{\mathrm{ab}}$ & $3.50^{\mathrm{ab}}$ \\
\hline Rark Phai & 3.50 & 4.75 & 2.87 & $5.87^{\mathrm{ab}}$ & $2.75^{\mathrm{ab}}$ \\
\hline Hom Klong Luang & 4.00 & 4.75 & 4.25 & $6.75^{\mathrm{ab}}$ & $3.75^{\mathrm{ab}}$ \\
\hline Leaung Kum Mad & 3.87 & 5.00 & 4.25 & $7.00^{\mathrm{a}}$ & $4.25^{\mathrm{ab}}$ \\
\hline Dore Khoa & 3.37 & 4.75 & 3.37 & $6.12^{\mathrm{ab}}$ & $3.75^{\mathrm{ab}}$ \\
\hline $\mathrm{Pa} \mathrm{Ma}$ & 3.25 & 4.25 & 3.12 & $5.12^{\mathrm{ab}}$ & $3.00^{\mathrm{ab}}$ \\
\hline Num Sa Kouy 19 & 3.50 & 4.87 & 3.62 & $6.62^{\mathrm{ab}}$ & $3.25^{\mathrm{ab}}$ \\
\hline Kun Dun Tia & 3.37 & 4.62 & 3.50 & $6.25^{\mathrm{ab}}$ & $2.50^{\mathrm{b}}$ \\
\hline San Pa Thong & 3.62 & 4.87 & 3.75 & $6.37^{\mathrm{ab}}$ & $2.75^{\mathrm{ab}}$ \\
\hline Pha Daeng & 4.12 & 4.87 & 4.00 & $6.25^{\mathrm{ab}}$ & $3.25^{\mathrm{ab}}$ \\
\hline Hom Dong & 3.62 & 4.75 & 3.37 & $5.87^{\mathrm{ab}}$ & $3.00^{\mathrm{ab}}$ \\
\hline Sumpun Deang & 3.75 & 4.75 & 4.12 & $6.37^{\mathrm{ab}}$ & $3.75^{\mathrm{ab}}$ \\
\hline Kaw Dor & 3.75 & 4.75 & 3.87 & $6.62^{\mathrm{ab}}$ & $3.00^{\mathrm{ab}}$ \\
\hline Kaen Doo & 4.12 & 5.00 & 4.12 & $6.87^{\mathrm{a}}$ & $3.75^{\mathrm{ab}}$ \\
\hline Nang Mon & 3.50 & 4.62 & 3.00 & $5.75^{\mathrm{ab}}$ & $3.75^{\mathrm{ab}}$ \\
\hline Hin Kong & 3.25 & 4.50 & 2.87 & $5.37^{\mathrm{ab}}$ & $3.25^{\mathrm{ab}}$ \\
\hline San Pla Lard & 3.62 & 4.87 & 3.87 & $6.37^{\mathrm{ab}}$ & $4.00^{\mathrm{ab}}$ \\
\hline Lueng Kaew & 3.50 & 4.62 & 3.25 & $5.75^{\mathrm{ab}}$ & $3.00^{\mathrm{ab}}$ \\
\hline Lueng Yai & 3.50 & 4.75 & 3.25 & $6.00^{\mathrm{ab}}$ & $2.75^{\mathrm{ab}}$ \\
\hline Nang Hok & 3.75 & 5.00 & 3.37 & $6.62^{\mathrm{ab}}$ & $3.25^{\mathrm{ab}}$ \\
\hline Kum Pay & 3.37 & 4.62 & 3.12 & $5.62^{\mathrm{ab}}$ & $2.50^{\mathrm{b}}$ \\
\hline Kore Deaw & 3.62 & 4.62 & 3.87 & $6.12^{\mathrm{ab}}$ & $4.50^{\mathrm{ab}}$ \\
\hline Kaw Muang & 3.50 & 4.37 & 3.37 & $5.87^{\mathrm{ab}}$ & $4.25^{\mathrm{ab}}$ \\
\hline Hom Nang Nuan & 4.25 & 4.87 & 4.37 & $6.62^{\mathrm{ab}}$ & $3.25^{\mathrm{ab}}$ \\
\hline Naew Deang & 3.62 & 4.75 & 3.50 & $6.00^{\mathrm{ab}}$ & $3.25^{\mathrm{ab}}$ \\
\hline Lueng Boon Ma & 3.62 & 4.50 & 3.37 & $5.37^{\mathrm{ab}}$ & $2.50^{\mathrm{b}}$ \\
\hline Hom Sakon & 3.87 & 4.87 & 4.12 & $6.62^{\mathrm{ab}}$ & $3.25^{\mathrm{ab}}$ \\
\hline Ku Muang Luang & 3.75 & 4.50 & 4.00 & $5.50^{\mathrm{ab}}$ & $3.00^{\mathrm{ab}}$ \\
\hline KDML 105 & 3.75 & 4.75 & 3.75 & $6.00^{\mathrm{ab}}$ & $3.00^{\mathrm{ab}}$ \\
\hline RD 6 & 4.12 & 5.00 & 4.37 & $6.37^{\mathrm{ab}}$ & $3.25^{\mathrm{ab}}$ \\
\hline
\end{tabular}

Mean values in the same column of the same group with the same letter(s) are not significantly different by Duncan's multiple range test $(p \leqslant 0.05)$.

grain dry weight, straw dry weight, root dry weight and shoot dry weight (Table 5).

Drought tolerance indexes for grain dry weight ranging from 0.39 in Som Ma Lee to 1.29 in Kaw Dor were observed among indigenous rice accessions, and there were 14 indigenous rice accessions having DTI for grain dry weight greater than 1 . The range of DTI for straw dry weight was from 0.62 in Rark Phai to 1.10 in Kum Pay. Among these indigenous rice accessions, there were seven accessions with DTI for straw dry weight greater than 1 .

DTI for root dry weight among the indigenous rice accession ranged from 0.80 in Hom Sakon to 1.36 in Lueng Boon Ma. It is interesting to note 
Table 5 DTI for grain dry, straw dry, root dry, and shoot dry weights of 40 indigenous rice accessions grown under early season drought from June to December in 2014 and 2015.

\begin{tabular}{|c|c|c|c|c|}
\hline Accession & Grain & Straw & Root & Shoot \\
\hline Som Ma Lee & $0.39^{\mathrm{n}}$ & $0.87^{\mathrm{a}-\mathrm{d}}$ & $1.07^{\mathrm{ab}}$ & $0.76^{b-f}$ \\
\hline Mali Dung Derm & $0.60^{\mathrm{k}-\mathrm{n}}$ & $0.99^{\mathrm{bc}}$ & $1.29^{\mathrm{ab}}$ & $0.88^{\mathrm{a}-\mathrm{f}}$ \\
\hline Khao Yai & $0.57^{1 \mathrm{mn}}$ & $0.83^{\mathrm{a}-\mathrm{d}}$ & $0.87^{\mathrm{ab}}$ & $0.79^{\mathrm{b}-\mathrm{f}}$ \\
\hline Laum Phou & $1.02^{\mathrm{a}-\mathrm{h}}$ & $1.06^{\mathrm{ab}}$ & $1.10^{\mathrm{ab}}$ & $1.02^{\mathrm{a}-\mathrm{c}}$ \\
\hline Ku Larb Dum & $1.01^{\mathrm{a}-\mathrm{h}}$ & $1.04^{\mathrm{abc}}$ & $1.18^{\mathrm{ab}}$ & $1.01^{\mathrm{a}-\mathrm{c}}$ \\
\hline Wid Nee & $0.80^{f-m}$ & $0.79^{\mathrm{a}-\mathrm{d}}$ & $0.83^{\mathrm{b}}$ & $0.79^{\mathrm{b}-\mathrm{f}}$ \\
\hline Pa Ka Amphuen & $0.91^{\mathrm{c}-\mathrm{j}}$ & $0.88^{\mathrm{a}-\mathrm{d}}$ & $1.06^{\mathrm{ab}}$ & $0.87^{\mathrm{a}-\mathrm{f}}$ \\
\hline E-Noi & $0.95^{\mathrm{c}-\mathrm{i}}$ & $0.86^{\mathrm{a}-\mathrm{d}}$ & $0.88^{\mathrm{ab}}$ & $0.86^{\mathrm{a}-\mathrm{f}}$ \\
\hline Kum Ka Dum & $0.74^{\mathrm{h}-\mathrm{m}}$ & $1.06^{\mathrm{ab}}$ & $1.06^{\mathrm{ab}}$ & $0.99^{\mathrm{a}-\mathrm{e}}$ \\
\hline Khao Park Mor & $0.53^{\mathrm{mn}}$ & $0.97^{\mathrm{a}-\mathrm{d}}$ & $1.14^{\mathrm{ab}}$ & $0.88^{\mathrm{a}-\mathrm{f}}$ \\
\hline Chao Deang & $0.57 \mathrm{l}^{\mathrm{mn}}$ & $0.87^{\mathrm{a}-\mathrm{d}}$ & $0.89^{\mathrm{ab}}$ & $0.81^{\mathrm{a}-\mathrm{f}}$ \\
\hline Rark Phai & $0.96^{\mathrm{b}-\mathrm{i}}$ & $0.62^{\mathrm{d}}$ & $0.97^{\mathrm{ab}}$ & $0.66^{f}$ \\
\hline Hom Klong Luang & $0.86^{\mathrm{d}-1}$ & $0.89^{\mathrm{a}-\mathrm{d}}$ & $1.03^{\mathrm{ab}}$ & $0.87^{\mathrm{a}-\mathrm{f}}$ \\
\hline Leaung Kum Mad & $1.08^{\mathrm{a}-\mathrm{g}}$ & $1.01^{\mathrm{abc}}$ & $1.05^{\mathrm{ab}}$ & $1.02^{\mathrm{a}-\mathrm{c}}$ \\
\hline Dore Khoa & $0.86^{\mathrm{d}-1}$ & $0.70^{\mathrm{bcd}}$ & $1.08^{\mathrm{ab}}$ & $0.72^{\text {def }}$ \\
\hline $\mathrm{Pa} \mathrm{Ma}$ & $0.83^{\mathrm{e}-1}$ & $0.82^{\mathrm{a}-\mathrm{d}}$ & $0.96^{\mathrm{ab}}$ & $0.83^{\mathrm{a}-\mathrm{f}}$ \\
\hline Num Sa Kouy 19 & $0.79^{g-m}$ & $0.78^{\mathrm{a}-\mathrm{d}}$ & $0.85^{\mathrm{ab}}$ & $0.79^{\mathrm{b}-\mathrm{f}}$ \\
\hline Kun Dun Tia & $0.69^{\mathrm{i}-\mathrm{m}}$ & $0.84^{\mathrm{a}-\mathrm{d}}$ & $0.83^{\mathrm{b}}$ & $0.80^{\mathrm{a}-\mathrm{f}}$ \\
\hline San Pa Thong & $0.91^{c-j}$ & $0.95^{\mathrm{a}-\mathrm{d}}$ & $0.83^{\mathrm{b}}$ & $0.93^{\mathrm{a}-\mathrm{f}}$ \\
\hline Pha Daeng & $0.91^{\mathrm{c}-\mathrm{j}}$ & $1.01^{\mathrm{abc}}$ & $1.26^{\mathrm{ab}}$ & $0.99^{a-e}$ \\
\hline Hom Dong & $1.18^{\mathrm{abc}}$ & $0.86^{\mathrm{a}-\mathrm{d}}$ & $1.17^{\mathrm{ab}}$ & $0.92^{\mathrm{a}-\mathrm{f}}$ \\
\hline Sumpun Deang & $1.10^{\mathrm{a}-\mathrm{f}}$ & $0.93^{\mathrm{a}-\mathrm{d}}$ & $1.29^{\mathrm{ab}}$ & $0.95^{\mathrm{a}-\mathrm{f}}$ \\
\hline Kaw Dor & $1.29^{\mathrm{a}}$ & $0.97^{\mathrm{a}-\mathrm{d}}$ & $1.11^{\mathrm{ab}}$ & $1.06^{\mathrm{ab}}$ \\
\hline Kaen Doo & $1.04^{\mathrm{a}-\mathrm{h}}$ & $1.03^{\mathrm{abc}}$ & $1.01^{\mathrm{ab}}$ & $1.03^{\mathrm{abc}}$ \\
\hline Nang Mon & $1.11^{\mathrm{a}-\mathrm{f}}$ & $0.90^{\mathrm{a}-\mathrm{d}}$ & $1.27^{\mathrm{ab}}$ & $0.93^{\mathrm{a}-\mathrm{f}}$ \\
\hline Hin Kong & $0.73^{\mathrm{h}-\mathrm{m}}$ & $0.98^{\mathrm{a}-\mathrm{d}}$ & $1.15^{\mathrm{ab}}$ & $0.91^{\mathrm{a}-\mathrm{f}}$ \\
\hline San Pla Lard & $0.76^{\mathrm{h}-\mathrm{m}}$ & $0.90^{\mathrm{a}-\mathrm{d}}$ & $1.20^{\mathrm{ab}}$ & $0.87^{\mathrm{a}-\mathrm{f}}$ \\
\hline Lueng Kaew & $0.93^{\mathrm{c}-\mathrm{j}}$ & $0.84^{\mathrm{a}-\mathrm{d}}$ & $0.96^{\mathrm{ab}}$ & $0.84^{\mathrm{a}-\mathrm{f}}$ \\
\hline Lueng Yai & $1.18^{\mathrm{abc}}$ & $0.90^{\mathrm{a}-\mathrm{d}}$ & $1.20^{\mathrm{ab}}$ & $0.93^{\mathrm{a}-\mathrm{f}}$ \\
\hline Nang Hok & $1.08^{\mathrm{a}-\mathrm{g}}$ & $0.98^{\mathrm{a}-\mathrm{d}}$ & $1.11^{\mathrm{ab}}$ & $1.00^{\mathrm{a}-\mathrm{c}}$ \\
\hline Kum Pay & $1.13^{\mathrm{a}-\mathrm{e}}$ & $1.10^{\mathrm{a}}$ & $1.28^{\mathrm{ab}}$ & $1.09^{\mathrm{a}}$ \\
\hline Kore Deaw & $0.84^{\mathrm{d}-1}$ & $0.77^{\mathrm{a}-\mathrm{d}}$ & $1.07^{\mathrm{ab}}$ & $0.78^{b-f}$ \\
\hline Kaw Muang & $1.15^{\mathrm{a}-\mathrm{d}}$ & $0.92^{\mathrm{a}-\mathrm{d}}$ & $1.33^{\mathrm{ab}}$ & $0.96^{\mathrm{a}-\mathrm{f}}$ \\
\hline Hom Nang Nuan & $0.80^{f-m}$ & $0.81^{\mathrm{a}-\mathrm{d}}$ & $1.21^{\mathrm{ab}}$ & $0.80^{\mathrm{a}-\mathrm{f}}$ \\
\hline Naew Deang & $0.89^{\mathrm{c}-\mathrm{k}}$ & $0.79^{\mathrm{a}-\mathrm{d}}$ & $1.02^{\mathrm{ab}}$ & $0.80^{\mathrm{a}-\mathrm{f}}$ \\
\hline Lueng Boon Ma & $1.01^{\mathrm{a}-\mathrm{h}}$ & $0.83^{\mathrm{a}-\mathrm{d}}$ & $1.36^{\mathrm{a}}$ & $0.85^{\mathrm{a}-\mathrm{f}}$ \\
\hline Hom Sakon & $1.26^{\mathrm{ab}}$ & $0.85^{\mathrm{a}-\mathrm{d}}$ & $0.80^{\mathrm{b}}$ & $0.91^{\mathrm{a}-\mathrm{f}}$ \\
\hline Ku Muang Luang & $0.89^{\mathrm{c}-\mathrm{k}}$ & $0.67^{\mathrm{cd}}$ & $0.90^{\mathrm{ab}}$ & $0.70^{\mathrm{a}-\mathrm{f}}$ \\
\hline KDML 105 & $0.99^{\mathrm{a}-\mathrm{i}}$ & $0.86^{\mathrm{ad}}$ & $0.92^{\mathrm{ab}}$ & $0.85^{\mathrm{a}-\mathrm{f}}$ \\
\hline $\mathrm{RD} 6$ & $0.63^{j-n}$ & $0.79^{\mathrm{a}-\mathrm{d}}$ & $1.17^{\mathrm{ab}}$ & $0.75^{\mathrm{c}-\mathrm{f}}$ \\
\hline
\end{tabular}

Mean values in the same column of the same group with the same letter(s) are not significantly different by Duncan's multiple range test $(p \leqslant 0.05)$.

here that there were 27 accessions with DTI for root dry weight greater than 1 , indicating that drought at early growth stage increased root growth in these indigenous rice accessions.

DTI for shoot dry weight ranging from 0.66 in Rark Phai to 1.09 in Kum Pay were observed among indigenous rice accessions. As with straw dry weight, there were seven accessions with DTI for shoot dry weight greater than 1 , indicating that drought at early growth stage reduced shoot growth to some extent.

\section{Cluster analysis}

A dendrogram based on grain yield, yield components and agronomic traits was used to divide the indigenous rice accessions into six distinct clusters (Fig. 1). Cluster A had 10 members, cluster B had nine accessions, cluster $\mathrm{C}$ consisted of six accessions, cluster D comprised four accessions, cluster $\mathrm{E}$ included eight accessions, and cluster $\mathrm{F}$ was formed of three accessions.

In cluster A, DTI for total dry weight, DTI for grain weight, and harvest index were low to intermediate, plant height was intermediate, total dry weight and root dry weight were intermediate to high, whereas straw weight and number of tillers/ plant were high.

In cluster B, straw weight and DTI for straw weight were low to intermediate, total dry weight was intermediate, and grain weight, DTI for grain weight and DTI for total dry weight were intermediate to high.

The unique features of cluster $\mathrm{C}$ consisted of a low harvest index, low to intermediate grain weight, intermediate DTI for grain weight, intermediate DTI for root dry weight, intermediate to high number of tillers/plant, intermediate to high number of grain/panicle, and intermediate to high root dry weight.

The accessions in group D were unique for: short height, low total dry weight, low straw weight, low root dry weight, low to intermediate grain weight, low to intermediate DTI for grain weight, low to intermediate leaf rolling score, low to intermediate DTI for root dry weight, intermediate harvest index, intermediate 1000-grain weight, intermediate to high panicles/plant, and intermediate to high unfilled grains/panicle.

The accessions in group $\mathrm{E}$ were unique for: low tiller number, low panicles, low to intermediate root dry weight, low to intermediate straw dry weight, intermediate to high plant height, intermediate to high harvest index, and intermediate to high DTI for grain weight.

The accessions in group $\mathrm{F}$ were unique for: low panicles/plant, low number of unfilled grains/panicle, low leaf rolling score, low to intermediate root weight, low to intermediate harvest index, low to 


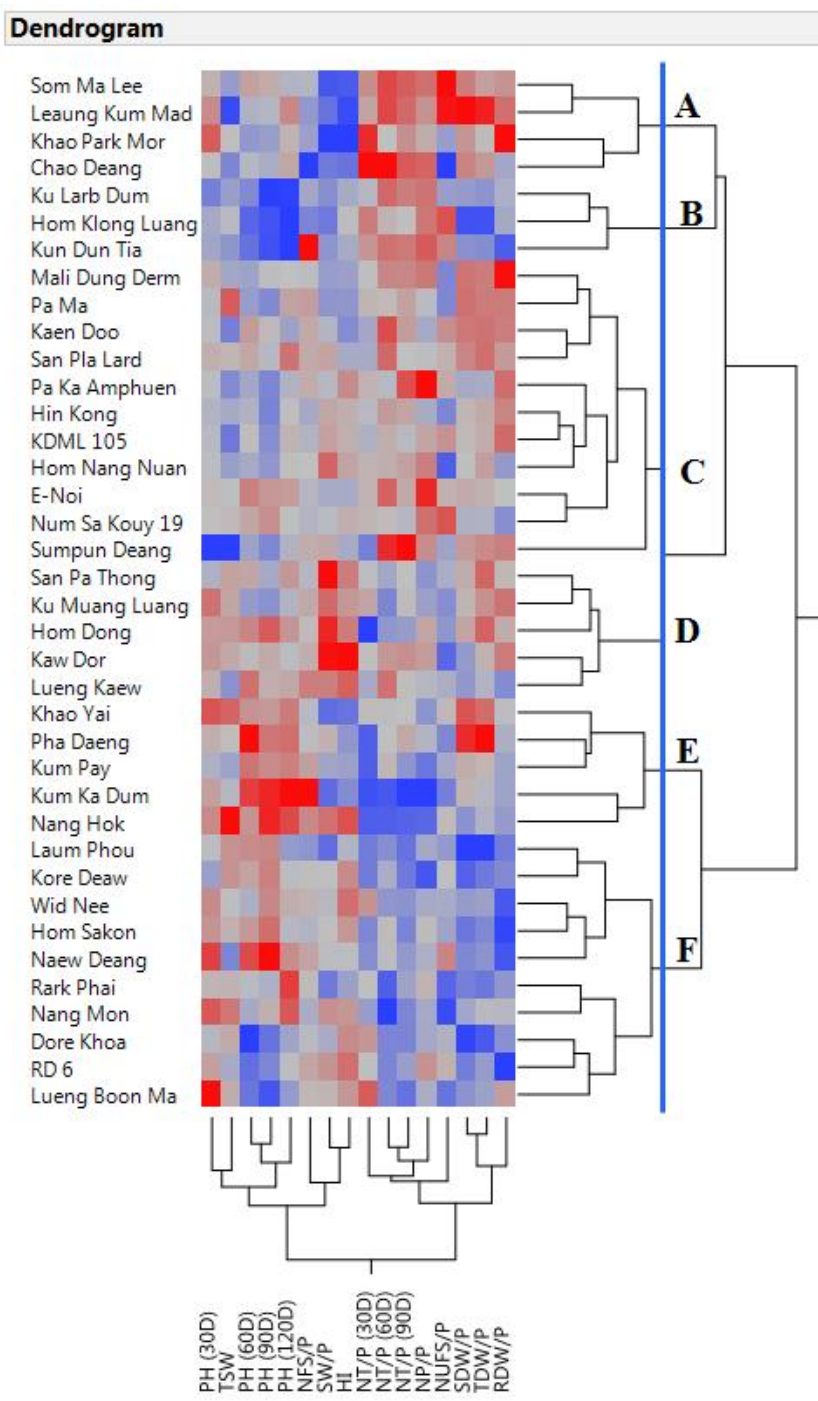

\begin{tabular}{|c|c|c|}
\hline $\mathrm{PH}$ (30D) & TSW & $\mathrm{PH}(60 \mathrm{D})$ \\
\hline 28.50 & 20.87 & 54.00 \\
\hline 33.89 & 22.76 & 59.91 \\
\hline 39.28 & 24.65 & 65.83 \\
\hline 44.67 & 26.53 & 71.74 \\
\hline 50.06 & 28.42 & 77.65 \\
\hline 55.46 & 30.31 & 83.5 \\
\hline 57.70 & 33.20 & 89.5 \\
\hline 59.95 & 36.08 & 95.5 \\
\hline 62.20 & 38.97 & 101.5 \\
\hline 64.45 & 41.85 & 107.5 \\
\hline 66.70 & 44.74 & 113.5 \\
\hline $\mathrm{PH}(120 \mathrm{D})$ & NFS/P & SW/P \\
\hline 91.70 & 7.10 & 13.70 \\
\hline 98.89 & 22.56 & 16.78 \\
\hline 106.09 & 38.02 & 19.86 \\
\hline 113.28 & 53.48 & 22.94 \\
\hline 120.47 & 68.94 & 26.01 \\
\hline 127.66 & 84.40 & 29.09 \\
\hline 132.33 & 97.20 & 33.25 \\
\hline 137.00 & 110.00 & 37.42 \\
\hline 141.67 & 122.80 & 41.58 \\
\hline 146.33 & 135.60 & 45.74 \\
\hline 151.00 & 148.40 & 49.90 \\
\hline NT/P (30D) & NT/P (60D) & NT/P $(90$ \\
\hline 4.10 & 6.40 & 12. \\
\hline 4.79 & 7.24 & 14. \\
\hline 5.47 & 8.09 & 16. \\
\hline 6.16 & 8.93 & 18. \\
\hline 6.85 & 9.77 & 20. \\
\hline 7.53 & 10.61 & 22. \\
\hline 8.65 & 11.35 & 25 . \\
\hline 9.76 & 12.09 & 27. \\
\hline 10.87 & 12.83 & 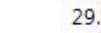 \\
\hline 11.99 & 13.56 &  \\
\hline 13.10 & 14.30 & \\
\hline NUFS/P & SDW/P & TDW/P \\
\hline 13.20 & 74.00 & 92.47 \\
\hline 16.13 & 82.45 & 103.06 \\
\hline 19.05 & 90.91 & 113.65 \\
\hline 21.98 & 99.36 & 124.24 \\
\hline 24.91 & 107.82 & 134.84 \\
\hline 27.83 & 116.27 & 145.43 \\
\hline 33.67 & 127.56 & 155.58 \\
\hline 39.50 & 138.84 & 165.74 \\
\hline 45.33 & 150.13 & 175.89 \\
\hline 51.17 & 161.41 & 186.05 \\
\hline 57.00 & 172.70 & 196.20 \\
\hline
\end{tabular}

PH (90D)

\begin{tabular}{rr} 
D) & PH (90D) \\
\hline 00 & 76.10
\end{tabular}

74.00
59.91
65.83

5.83
7.7 .20

71.74
77.65

82.30
9

77.65
$83.57-96.35$

101.26

101.26
106.17

111.08

115.99
$\quad 120.90$

W/P HI

0.10

0.12

0.17
0.94

0.19
$2.01-0.21$

0.21

0.24

0.26
$-\quad 0.29$

0.31

NP/P

NP/P
11.10
12.69

12.69

14.28

14.28

15.87

17.47

19.06

20.31

21.55

22.80

24.05

25.30

RDW/P

15.93

19.29

22.65

26.01

29.37

32.73

41.36

45.68

49.99

54.31

Fig. 1 A dendrogram classified indigenous rice accessions into six distinct groups based on plant height, number of tillers/plant, number of panicle/plant, number of filled seeds/panicle, number of unfilled seeds/panicle, 1000-grain weight, straw dry weight/plant, total dry weight/plant and harvest index.

intermediate leaf death score, intermediate 1000grain weight, intermediate straw dry weight, intermediate total dry weight, intermediate to high DTI for root dry weight, high DTI for straw weight, high DTI for total dry weight, high number of filled grains, and tall plant heights.

As Kalasin province was the largest collection site (13 accessions), it dominated in clusters A, B, $\mathrm{C}$, and E. KKRRC had nine accessions and it dominated in cluster D, Yasothon province dominated in cluster B and Maha Sarakham province dominated in cluster $C$ together with Kalasin Province. SRRC did not dominate in any cluster but it distributed in clusters A, B, C, and E.

\section{DISCUSSION}

\section{Year and water regime}

Although the experiment was undertaken in containers in an open-environment condition, crop performances for most characters differed between years. Environment is the important factor affecting growth and yield of many crops ${ }^{15}$. Furthermore, there were significant effects of genotype by environment interactions for most traits under investigation. In a previous study, one early season drought in rice, significant water regime $\times$ treat- 
ment interactions $(p \leqslant 0.001)$ were observed for most morpho-physiological parameters ${ }^{16}$. Multienvironment traits might reveal the rice genotypes that are superior for yield and other agronomic traits ${ }^{17}$. The results indicated the importance of genotype by environment interactions, and extensive evaluation of the crop is necessary to identify the superior genotypes.

Crops respond to the early season differently. In general, drought at any growth stage is more or less detrimental to rice growth and yield ${ }^{18}$. However, the effect of drought on rice increased with plant growth and drought had larger detrimental influences during the reproductive phase (e.g., blooming stage, filling stage, and maturity) ${ }^{19}$. Drought stresses at different moisture levels reduced grain yield from $48.5-92 \%$ over control trials ${ }^{20}$. In this study, early season drought reduced grain weight/ plant, straw weight/plant and shoot dry weight/ plant of indigenous rice accessions but it increased plant height at 30 and $60 \mathrm{DAE}$, number of filled grains/ear, 1000-grain weight and root dry weight. However, water regime did not significantly affect the number of tillers/plant at $30 \mathrm{DAE}$ or the harvest index. Some indigenous Thai varieties would be useful as parents for developing drought-tolerant and high-yield cultivars.

\section{Agronomic traits}

Variations in agronomic traits are important for crop breeding both for selecting parents to generate segregating populations and selecting superior genotypes in segregating populations. In this study, the accessions with good agronomic traits were identified for further use in indigenous rice breeding programs.

Plant height is an important trait for rice. However, plant height should be suitable for cultivation. Very short plant height is associated with low yield potential and extremely tall plant height is associated with lodging. Variation in plant height was rather high and some accessions were selected for breeding purposes.

A high tiller number is preferable for rice as this trait is associated with high ear number and yield. Chao Deang was highest for this trait and Kun Dun Tia was highest for ear number. This study was able to identify other accessions with interesting traits, such as Kaw Muang for numbers of filled grains, Mali Dung Derm for root dry weight and Kaw Dor for harvest index.

\section{Traits related to drought resistance}

In this study, indigenous rice accessions were evaluated for leaf rolling score and drought scoring and drought recovery to screen for drought tolerance in these rice accessions. The variation in leaf rolling in this study was low, indicating that leaf rolling was not a good trait for evaluating drought tolerance in this germplasm. However, significant variations in drought scoring and drought recovery were observed in these indigenous rice accessions, indicating the usefulness of these traits in screening drought tolerance in these rice accessions.

In rice and other crop species, drought tolerance index (DTI) has been used as a tool for selecting drought-tolerant genotypes ${ }^{21,22}$. In this study, drought tolerance indexes for grain dry weight, straw dry weight, root dry weight and shoot dry weight were used in identifying indigenous rice accessions with resistance to drought. Drought tolerance index greater than 1 indicated that the genotype should be resistant to drought for the trait under study. In this study, the results show that 14 accessions had high DTI for grain dry weight, seven accessions had high DTI for straw dry weight, 27 accessions had high root dry weight, and seven accessions had high DTI for shoot dry weight.

\section{Cluster analysis}

In this study, the indigenous rice accessions were not collected primarily from the farmers but instead were collected from secondary sources. The rice accessions from the collection locations were distributed in all groups. The authors did not observe any clear pattern or relationships among the collection locations except for Maha Sarakham and Kalasin, which were somewhat closely related. However, the authors found the dominance of the collection locations in each group.

According to Promsomboon et $\mathrm{al}^{23}$, the distribution of indigenous rice in Thailand was related to agro-ecosystems, including lowland, upland and deep water ecosystems. As indigenous rice has long been cultivated in Thailand, rice accessions have been distributed across the different regions, which resulted in rice exchange and relocation of populations, who, in turn, generally carried rice with them to new settlements. In the upland rice variety grown by Karen people in different villages, the genetic diversity in the same variety was found due to geographic isolation of the variety ${ }^{24}$. The relationship observed between Maha Sarakham and Kalasin could possibly be due to the locations being 
adjacent to one another. Molecular markers might reveal the genetic relationships among the indigenous rice accessions ${ }^{25}$, and further investigations are still required.

Acknowledgements: This study was funded by the Research and Development Institute, Rajabhat Maha Sarakham University. The authors would also like to acknowledge the Faculty of Agricultural Technology, Rajabhat Maha Sarakham University and the Faculty of Agriculture, Khon Kaen University for providing research facilities.

\section{REFERENCES}

1. Office of Agricultural Economics (2019) Agricultural Statistics of Thailand 2018. Available online: www.oae.go.th/assets/portals/1/files/jounal/ 2562/yearbook2561.pdf. [in Thai]

2. Bermier J, Atlin GN, Serraj R, Kumar A, Spaner D (2008) Breeding upland rice for drought resistance. J Sci Food Agr 88, 927-39.

3. Rahman MS, Yoshida S (1985) Effect of water stress on grain filling in rice. Soil Sci Plant Nutr 31, 497-511.

4. Luo LJ (2010) Breeding for water-saving and drought-resistance rice (WDR) in China. $J$ Exp Bot 61, 3509-17.

5. Narenoot K, Monkham T, Chankaew S, Songsri P (2017) Evaluation of the tolerance of Thai indigenous upland rice germplasm to early drought stress using multiple selection criteria. Plant Genet Resour C 15, 109-18.

6. Ninsuwan U, Ninsuwan $M$, Khucharoenphaisarn $K$ (2014) Clustering analysis of salinity responses in indigenous rice by sorting algorithm. Khon Kaen Agr $J$ 42, 91-8.

7. Yesmin N, Elias SM, Rahman MDS, Haque T, Hasan AKMM, Seraj ZI (2014) Unique genotypic differences discovered among Indigenous Bangladeshi rice landraces. Int J Genomics 2014, 1-11.

8. Panda T, Mishra N, Mohanty RB (2013) Diversity of some threatened indigenous rice varieties cultivated in Odisha, India. Environ Nat Resour J 11, 41-57.

9. Doorenbos J, Pruitt WO (1992) Crop Water Requirements. FAO Irrigation and Drainage Paper No. 24, Rome, Italy.

10. De Datta SK, Malabuyoc JA, Aragon EL (1988) A field screening technique for evaluating rice germplasm for drought tolerance during the vegetative stress. Field Crop Res 19, 123-34.

11. IRRI (1996) Standard evaluation system for rice. The International Rice Research Institute, Manila, the Philippines.
12. Nautiyal PC, Rachaputi NR, Joshi YC (2002) Moisture-deficit-induced changes in leaf-water content, leaf carbon exchange rate and biomass production in groundnut cultivars differing in specific leaf area. Field Crop Res 74, 67-79.

13. Gomez KA, Gomez AA (1984) Statistical Procedures for Agricultural Research, John Wiley \& Sons, New York.

14. Bricker AA (1989) MSTAT-C User's Guide, Michigan State University, Michigan.

15. Chen G, Wang S, Huang X, Hong J, Du L, Zhang L, Ye L (2015) Environmental factors affecting growth and development of Banlangen (Radix Isatidis) in China. Afr J Plant Sci 9, 421-6.

16. Singh B, Reddy KR, Diaz Redona E, Walker T (2017) Screening of rice cultivars for morpho-physiological responses to early-season soil moisture stress. Rice Science 24, 322-35.

17. Balakrishnan D, et al (2016) Genotype $\times$ environment interactions of yield traits in backcross introgression lines derived from Oryza sativa cv. Swarna/Oryza nivara. Front Plant Sci 7, 1-19.

18. Moonmoon S, Islam MT (2017) Effect of drought stress at different growth stages on yield and yield components of six rice (Oryza sativa L.) genotypes. Fundam Appl Agric 2, 285-9.

19. Zhang J, et al (2018) Effect of drought on agronomic traits of rice and wheat: A meta-analysis. Int $J$ Environ Res Public Health 15, 1-14.

20. Saikumar S, Varma CMK, Saiharini A, Kalmeshwer GP, Nagendra K, Lavanya K, Ayyappa D (2016) Grain yield responses to varied level of moisture stress at reproductive stage in an interspecific population derived from Swarna/O. glaberrima introgression line. NJAS-Wagen J Life Sc 78, 111-22.

21. Kim SH, Kim DY, Yacoubi I, Seo YW (2014) Phenotypic and genotypic analyses of drought tolerance in Korean and Tunisian wheat cultivars. Plant Breed Biotech 2, 139-50.

22. Narenoot K, Monkham T, Chankaew S, Songsri P, Pattanagul W, Sanitchon J (2017) Evaluation of the tolerance of Thai indigenous upland rice germplasm to early drought stress using multiple selection criteria. Plant Genet Resour C 15, 109-18.

23. Promsomboon P, Promsomboon S (2016) Collection and evaluation of local Thai rice varieties (Oryza sativa L.). J Life Sci 10, 371-4.

24. Pusadee T, Jamjod S, Chiang YC, Rerkasem B, Schaal BA (2009) Genetic structure and isolation by distance in a landrace of Thai rice. PNAS 106, 13880-5.

25. Chakhonkaen S, Pitnjam K, Saisuk W, Ukoskit K, Muangprom A (2012) Genetic structure of Thai rice and rice accessions obtained from the International Rice Research Institute. Rice 5, 1-13. 